\title{
THE FAREWELL SERMON OF PROPHET MUHAMMAD: AN ANALYTICAL REVIEW
}

\author{
Mohammad Omar Farooq *
}

\begin{abstract}
Historically, the Farewell Sermon (khutbah al-wida) of the Prophet Muhammad (pbuh) $)^{1}$ has occupied an important place in Islam. The sermon was delivered during the Farewell Hajj (pilgrimage), on 9 Dhu al-Hijja 10AH (6 March 632), at Mount Arafat. The sermon consisted of summarised exhortations reflecting some of the core teachings of the Qur'an and Sunnah. There are multiple versions of the sermon, with no single consolidated source being in existence. The sermon therefore seems to have been weaved from multiple sources over time. This brief essay examines the substance of the Farewell Sermon based on its various versions and presents an analysis to determine whether it should be more appropriately called the 'Farewell Message'.
\end{abstract}

Keywords: Muhammad; Farewell Pilgrimage; Farewell Sermon; Hajj; Khutbah al-wida.

\section{Introduction}

The life of the Prophet Muhammad (pbuh) culminated in the events of the Farewell Pilgrimage. Some narrations indicate that he anticipated that this would be the last major hajj gathering for him. For the period, this was a historic, massive gathering, as it also happened to be hajj akbar (major hajj), a hajj that coincides with Jum 'ah (Friday) prayer. The Prophet utilised this august occasion to deliver his Farewell Sermon, underscoring some key aspects of Islam while also conveying his major concerns regarding fundamental challenges and tribulations facing the ummah.

Any educated or informed Muslim is generally familiar with the Farewell Sermon, or at least various parts of it, because some of the statements in this sermon became statements of principle. The main purpose of this article is to help readers appreciate the beauty of this sermon and to reflect on some general and specific issues concerning it. Most notably, we consider how, contrary to popular belief, the text of the sermon as we have it is a composite, not a single narrated piece. That's why it is more appropriate to call it the 'Farewell Message' rather than Farewell Sermon. While this does not lessen the relevance or value of the sermon, the sermon does not have to be sanctified as one single speech. 
The analysis in this paper is based on the primary collections of hadith (Prophetic narrations), with priority being given to these over history (tarikh) or biography (sirah) resources, and based on the premise that anything attributed to the Prophet must be consistent with the Qur'an. The rest of the paper is divided into the following sections: the importance and legacy of the sermon; review of the sources of the sermon; some general observations and premises; the main themes of the sermon; and a general analysis of those main themes.

In modern times, Islam's historical sources are being explored and scrutinised with ever more intensity, both positive and negative. Instead of letting those with negative biases scrutinise and expose weaknesses in popular narratives, pursuit of truth and accuracy desires that Muslims themselves take the lead in any critical approach to the study and understanding of their own faith and, wherever appropriate, to try and set the record straight.

\section{The Importance of Legacy of the Sermon}

Known as the Farewell Sermon, it took place on 9 Dhu al-Hijjah 10 AH (6 March $632 \mathrm{AD}$ ), during the Hajj. The relevance of 'farewell' in this context is that in this sermon there is a hint that the Prophet (pbuh) would be returning to his Lord soon. Indeed, he passed away just a few months later. This sermon is commonly recognised as a single sermon, but in fact, at best, it is a composite of various statements made during the Hajj ceremony:

The Farewell Sermon is a compilation of several sermons which were delivered at different times in Mina, Muzdalifa, and Arafat during the Prophet's pilgrimage in AH 10 (631). The Prophet addressed more than 100,000 believers who were observing the hajj, the major pilgrimage to the sacred precincts in Mecca...The Prophet delivered his sermon in different locations and heralds repeated his words to the great number of people who attended. This sermon was called 'Farewell' Sermon because in this sermon the Prophet implied that he would soon die and that he would not be able to perform the pilgrimage another time. The days-to-come bore out this predication and he was reunited with his Beloved with[in] three months of the final sermon. ${ }^{2}$

The sermon's transcending importance and status cannot be overemphasised, especially given the context wherein it occurred, that it constituted the Prophet Muhammad's (pbuh) last such sermon, and due to the message it contained.

With his Farewell Sermon, Muhammad abolished these time and place limitations on human rights, thus universalising human inviolability to 
all times and places. This was a large step away from traditional Arab custom and could easily be rejected by the community. The Prophet thus emphasised his injunction through the prominence of his wording as well as the time and place he uttered it. The sermon was delivered during the hajj, which took place at a sacred time and in a sacred place, and he repeated his injunction several times on several occasions. He also made it explicit that this injunction was from God and that God was the witness when Muhammad conveyed it to the people. Muhammad spoke as a prophet of God but also as a state leader and a lawmaker. ${ }^{3}$

The Sermon has been treasured by Muslims, not just as a sacred sermon, but also as a sermon of univeralist orientation with contemporary, modern relevance.

The Farewell Sermon has been rediscovered and put to a new use by Muslims in support of the 1948 United Nations Declaration of Universal Human Rights. From this modern perspective, the Farewell Sermon constitutes what could be considered an earlier attempt at a human rights declaration. This view is advance to serve both ... as a justification to enhance human rights compliance by Muslim societies and states.

Down through the generations, the teachings and practice of the Prophet Muhammad pertaining to human rights have been interpreted differently. The universalist Muslim jurists extrapolated from them universal human rights for all people around the world regardless of their religion and citizenship. ${ }^{4}$

The Farewell Sermon of Prophet Muhammad vividly illustrates his contribution to the development of human rights and how he laid the foundations of the idea of universal human rights in a world previously dominated by tribalism. ${ }^{5}$

This is a landmark speech, comparable to Jesus's Sermon on the Mount, which will remain part of humanity's legacy, with a very special place in the annals of human history. ${ }^{6}$ To Muslims, of course, it means more than that.

Some non-Muslim scholars have been skeptical about the "textual authenticity" of the sermon. ${ }^{7}$ However, this skepticism is not necessarily about the content of the sermon, as this basically corresponds to the teachings of the Qur'an. Rather, doubts seem to be directed at the assumption that the sermon is one whole piece, not a composite constructed from fragments of Prophetic sayings. 


\section{Review of the Sources of the Sermon}

There are two types of sources for this sermon: (a) hadith and (b) history/biography. From amongst the second category, the longest versions are available in Sirah Ibn Ishaq by Muhammad Ibn Ishaq (d.761) and Kitab al-Bayan wa al-Tabiyin by al-Jahiz al-Basri (d.869). However, historical/biographical sources are less rigorous and are not based on any process of authentication of the sources. Thus, in this work of limited scope only hadith sources have been used, since hadith supposedly preserve the sayings and actions of the Prophet (pbuh) accurately. Seven hadith collections are covered in this study, including the Sihah Sitta ${ }^{8}$ (the six canonical texts: Sahih al-Bukhari, Sahih Muslim, Sunan Abu Dawood, Jami at-Tirmidhi, Sunan Ibn Majah and Sunan an-Nasai) and the Musnad Ahmad of Imam Ahmad Ibn Hanbal. While there are many other secondary collections, most of those are dated later than these selected texts and have not earned the same kind of reputation and stature within the Muslim scholarly community.

\section{Some General Observations and Premises}

The longer versions of the sermon are not available in the hadith collections, but rather only in the biographies and histories, which are less reliable as sources. The versions in the hadith are much shorter and appear in scattered fragments. The themes covered in the sermon are placed under different headings in a table of the seven hadith collections produced as an appendix at the end of this article, which can be referred to for the purpose of comparison.

\section{Theme \#1: Sanctity}

Only Sahih al-Bukhari and Musnad Ahmad mention the Prophet (pbuh) posing questions to the congregation about the month, day, city, etc. The other five collections do not mention those questions. Given that this sermon was before the largest gathering ever in the life of the Prophet, it is anomalous that five of the seven collections studied here do not mention those conversational queries at all.

\section{Theme \#2: Transition from Jahiliyyah (the Age of Ignorance)}

The reference to Jahiliyyah and the society's coming out of it is mentioned only in Sahih Muslim and Sunan Abu Dawood. The other five do not mention it. The Qur'an mentions about Jahiliyyah when inviting the people to light and illumination of Islam:

Then is it the judgement of [the time of] Jahiliyyah they desire? But who is better than Allah in judgement for a people who are certain (in faith). (Surah Al-Ma'idah, 5:50). 


\section{Theme \#3: Freedom from bloodshed}

Abolition of all prior claims to blood revenge is mentioned only in Sahih Muslim and Sunan Abu Dawood. The other five do not mention it. Sanctity of human life is emphatically and universally mentioned in the Qur'an:

Because of that, We decreed upon the Children of Israel that whoever kills a soul unless for a soul or for corruption [done] in the land - it is as if he had slain mankind entirely. And whoever saves one - it is as if he had saved mankind entirely. And our messengers had certainly come to them with clear proofs. Then indeed many of them, [even] after that, throughout the land, were transgressors. (Surah al-Maidah, 5: 32)

\section{Theme \#4: Riba (Abolition)}

As part of this Farewell Sermon, the theme of riba (usually equated with interest) and its prohibition/abolition is mentioned only in Sahih Muslim and Sunan Abu Dawood. The other five do not mention it. Riba is categorically prohibited in the Qur'an:

Those who consume riba cannot stand [on the Day of Resurrection] except as one stands who is being beaten by Satan into insanity. That is because they say, "Trade is [just] like riba." But God has permitted trade and has forbidden riba. So whoever has received an admonition from his Lord and desists may have what is past, and his affair rests with God. But whoever returns to [dealing in riba] - those are the companions of the Fire; they will abide eternally therein. (Surah alBaqarah, 2: 275).

Riba is serious matter for society, as it is directly related to zulm (injustice and exploitation). A society that values Islam should try to eliminate the deleterious effects of riba as well as any other source of zulm.

\section{Theme \#5: Gender issues}

Gender issues are generally thought to feature prominently in the Farewell Sermon. However, only three hadith collections (Sahih Muslim, Sunan Ibn Majah and Jami al-Tirmidhi) deal with it specifically. The longest coverage of gender issues occurs in Sunan Ibn Majah. Moreover, only Ibn Majah specifically mentions the reciprocity of rights between men and women. The other four are silent regarding this gender-related theme.

Also, only Sahih Muslim and Sunan Ibn Majah mention the permissibility of chastising women (without being harsh or injurious). The others do not 
mention this aspect. This part of the message is consistent with the orthodox, literal and non-contextual understanding of Qur'anic verse 4:34. However, this orthodox understanding is being questioned. ${ }^{9}$ Notably, contemporary female Muslims scholars are challenging this orthodox understanding and interpretation, considering it the source of an abusive culture in generally male-dominant Muslim societies. ${ }^{10}$

Indeed, the orthodox interpretation is inconsistent with the later verse 9:71, which presents gender relationships in the framework of mutual guardians or patrons (awliya):

The believers, men and women, are guardians/patrons (awliya) of one another. They enjoin the 'common good' (al-ma 'ruf) and forbid the bad (al-munkar), they observe prayers (salat) and give charitable alms (zakat) and obey God and his Prophet.

Mutual guardianship (wilayah) is inconsistent with the orthodox, literal understanding of 4:34. As the Qur'anic verses have been revealed in stages, with specific examples, as in the case of prohibition of intoxicants (khamr), where later revelations abrogate earlier ones, the latter must therefore be given due priority when defining and taking a position on such issues. Such a perspective must be understood in the context of Islam's hierarchy of values. ${ }^{11}$

\section{Theme \#6: Legacy and Witness}

Except Jami al-Tirmidhi and Sunan an-Nasai, all the collections mention about the Prophet asking the congregation to witness and spread his message to those who were absent.

Only Sahih al-Bukhari and Sunan Ibn Majah, however, mention the stern warning from the Prophet that after him the Muslims should not become disbelievers, striking the necks of each other.

Quite importantly, a theme that has become critical to Islam is that the Prophet apparently mentioned leaving something behind that, should the believers adhered to it, would keep them from going astray. This matter, in the context of the sermon, is mentioned only in Sahih Muslim, Sunan Ibn Majah and Jami al-Tirmidhi. Other collections are silent. Even more notably, Sahih Muslim and Sunan ibn Majah only mention the Qur'an within this context, unlike many other hadith that (in other contexts) mention two things: the Qur'an and Sunnah or the Qur'an and the Ahl al-Bayt (the Prophet's household). Given that this was his Farewell Sermon, delivered openly to a large congregation, if the Prophet mentioned only the Qur'an this would be significant. In Jami al-Tirmidhi, both the Qur'an and Ahl al-Bayt are mentioned. ${ }^{12}$ 
It should be noted that the two things - the Qur'an and Sunnah - are not mentioned like this in the Sihah Sittah. They are mentioned in other sources, such as the Muwatta of Imam Malik ${ }^{13}$ and al-Mustadrak of Hakim al-Nisharburi. ${ }^{14}$ Another version with two weighty things (thaqalain) is mentioned in only Sahih Muslim (as part of Sihah Sitta). ${ }^{15}$

This issue of leaving behind something to guide Muslims has another anomalous aspect. We see that none of the hadith concerning the Farewell Sermon in Sihah Sitta mention both the Qur'an and Sunnah in this context. However, Sirah Ibn Ishaq does mention both the Qur'an and Sunnah. ${ }^{16}$ Another long version, much later than Ibn Ishaq, is by al-Jahiz and mentions only the Qur'an, without the Sunnah. ${ }^{17}$ But whether it is only the Qur'an, or the Qur'an and Ahl al-Bayt (itrah), or the Qur'an and the Sunnah, a related anomaly is found when one compares the Farewell Sermon with an incident that occurred around the Prophet's death bed. According to many hadiths, including in Sihah Sitta, shortly before his death, the Prophet (pbuh) asked those around him to bring him a piece of paper so that he could dictate something that, if the believers followed it, would stop them from going astray. However, there was a commotion and confusion, which prevented the Prophet (pbuh) from dictating whatever he had in mind:

When the time of the death of the Prophet approached while there were some men in the house, and among them was 'Umar bin Al-Khatttab, the Prophet said, "Come near let me write for you a writing after which you will never go astray." "Umar said, "The Prophet is seriously ill, and you have the Qur'an, so Allah's Book is sufficient for us." The people in the house differed and disputed. Some of them said, "Come near so that Allah's Messenger may write for you a writing after which you will not go astray," while some of them said what "Umar said. When they made much noise and differed greatly before the Prophet, he said to them, "Go away and leave me." Ibn `Abbas used to say, "It was a great disaster that their difference and noise prevented Allah's Messenger from writing that writing for them."18

This raises an important question. The Prophet (pbuh) had already pronounced openly before the largest congregation during his life that he was leaving behind one (the Qur'an) or two things (the Qur'an and the Sunnah, or the Qur'an and Ahl al-Bayt). So why again the idea of needing to write down something which, if followed, would prevent the Ummah from going astray?

\section{Theme \#7: The Repudiation of Racism}

One of the most salient aspects of the Farewell Sermon is the repudiation of all forms of racism, with it being explicitly affirmed that no Arab has any superiority 
over a non-Arab, or a White over a Black, except in taqwa (God consciousness). This resonates with the Qur'anic verse:

O mankind, indeed We have created you from male and female and made you peoples and tribes that you may know one another. Indeed, the most noble of you in the sight of God is the most righteous (GodConscious - having taqwa) of you. Indeed, God is Knowing and Acquainted. (Surah al-Hujurat, 49: 13).

Quite remarkably, this repudiation is not included in any of the Sihah Sittah. It is mentioned only in Musnad Ahmad. Also, a report circulated in some contemporary writings that the sermon included a statement that there was no superiority of one gender over another. However, that seems to be a clear misattribution, as no early source mentions this. ${ }^{19}$

\section{Theme \#8: Obedience/Adherence}

The theme regarding the importance of obeying those in authority, even if that person be a black slave, is mentioned only in Sahih Muslim. It is not mentioned in any of the other six collections. This obedience is not unconditional, meaning that it does not apply to those who grab power, by whatever means. This obedience is only to those in leadership who have been appointed by people through their free and mutual consent and those who adhere to the guidance of God. Adherence should not be accorded to those whose footsteps are not on the path of God and His Messenger:

O you who have believed, obey God and obey the Messenger and those in authority among you. And if you disagree over anything, refer it to God and the Messenger, if you should believe in God and the Last Day. That is the best [way] and best in result. (Surah an-Nisa, 4: 59).

\section{Theme \#9: Rights}

That all rights originate from God, and that He has given due rights to everyone, is mentioned only in Sunan Ibn Majah, not in any of the other six.

\section{Theme \#10: Salat/Zakat}

The theme of salat/zakat in the context of the Farewell Sermon is mentioned in only one collection: Jami al-Tirmidhi. The other six collections do not mention it. As salat and zakat are clearly and frequently mentioned in the Qur'an, separate mention in the sermon is not warranted. The point is that, if it had been included in the sermon, it is notable that only one of the hadith collections includes it as part of the sermon. 


\section{Theme \#11: Debt}

The theme affirming the importance of repaying debt and honouring promises and guarantees is mentioned only in Jami al-Tirmidhi.

\section{Analysis of the Themes}

Having identified all these themes and how they appear in these seven collections, it is important to note that it is quite possible that different narrators/reporters from those who were in attendance at the Farewell Sermon picked up bits and pieces of the narrative. It is also possible that the narrators/reporters have narrated selectively, as per what they perceived to be important or relevant in a particular context.

However, several important things should be noted.

Given that there are so many, rather long hadiths in various collections ${ }^{20}$ it is puzzling as to why there is no one single complete narration of this special, historic sermon. What is available seems to be a composite that a later generation has put together from bits and pieces. Thus, whenever the sermon is shared or mentioned, it should be noted that it is actually a composite of many fragments.

The variation in the coverage of the narrations in these seven hadith collections is so huge that one should be careful when drawing firm conclusions, positions or rulings based on any aspect of this sermon. A more appropriate reference is the Qur'an and the legacy of the Prophet.

Yet, except for some aspects of the gender issue (e.g. the issue of chastising women in certain situations), which are seriously questionable, the sermon does affirm some core values and principles of Islam and reflect the essential message of Islam. However, since this sermon is based on fallible human narrative, its contents should be scrutinised in the light of the Qur'an, which is the only Divine source in Islam.

\section{Conclusion}

The purpose of this paper was to explore what is popularly known as the Farewell Sermon of the Prophet Muhammad (pbuh). Even when not viewed through a Muslim religious lens, this address undoubtedly constitutes a valuable treasure for all humanity. From the viewpoint of the Muslims, however, it was the Prophet's final, formal address to the faithful, through which he aimed to reach all humanity. However, to call it a sermon is problematic. As explained and documented in this paper, the address seems to be a composite of bits and pieces picked up by various narrators, as presented through various hadith collections. 
Lacking one single rendition and abounding in variation, it is more appropriate to identify and present it as a Farewell Address or Farewell Message.

\section{Recommendations}

1. Given the profound importance of the Farewell Sermon or Message, it should be more systematically and widely disseminated among nonMuslims as well as Muslims, especially the younger generation, with aspirations of civilisational renewal.

2. Muslims should take the synoptic message given during the last pilgrimage of the Prophet (pbuh) to identify and determine their contemporary priorities.

3. Though delivered to the largest congregation of his time and, through them, to future Muslim generations, as Islam is universalistic (ukhrijat lin-nas, see al-Qur'an 3:110), so was this Farewell Message, with humanity as its target audience. Muslims need to re-embrace and uphold that universalistic, humanity-orientation in their thoughts and actions, individually and collectively. 







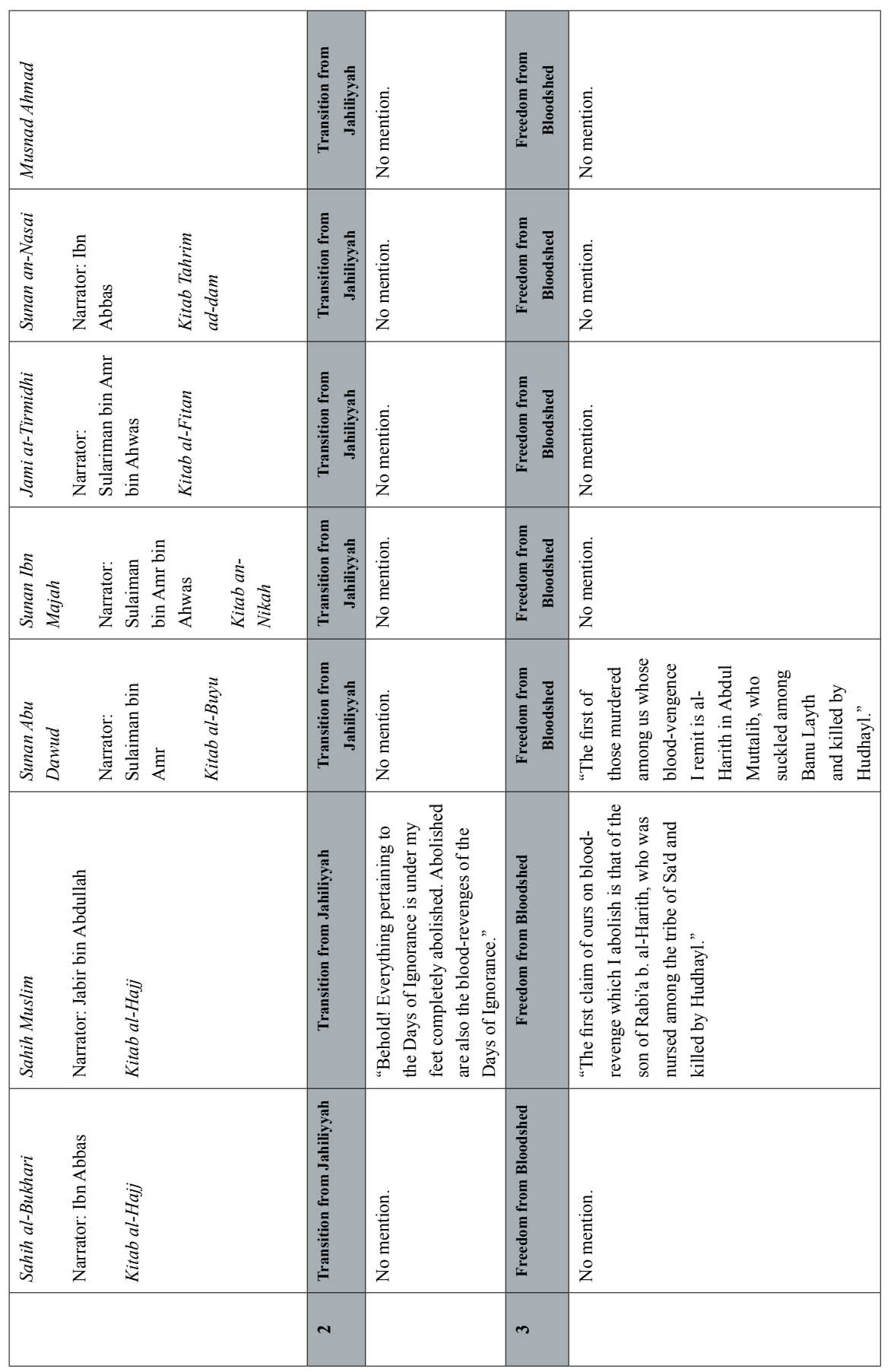




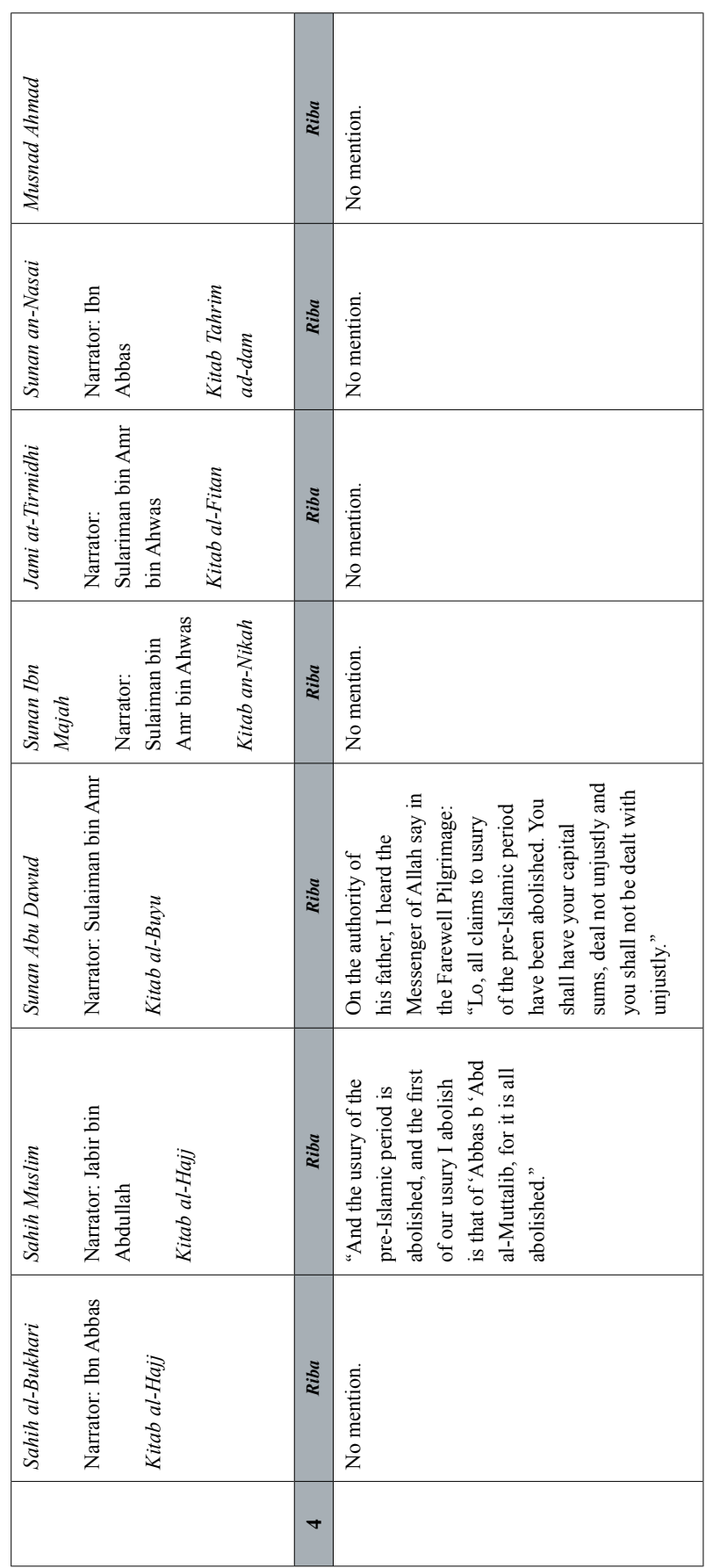




\begin{tabular}{|c|c|c|c|c|c|}
\hline 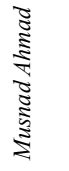 & & & & 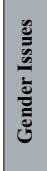 & 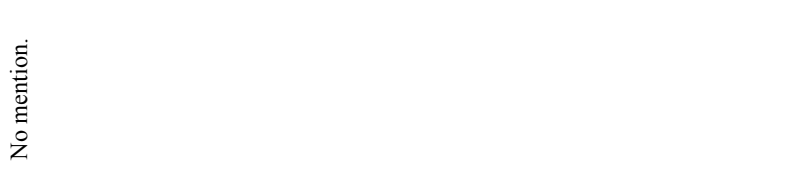 \\
\hline 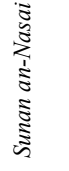 & 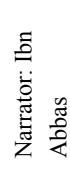 & & 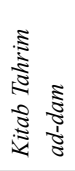 & 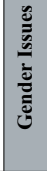 & 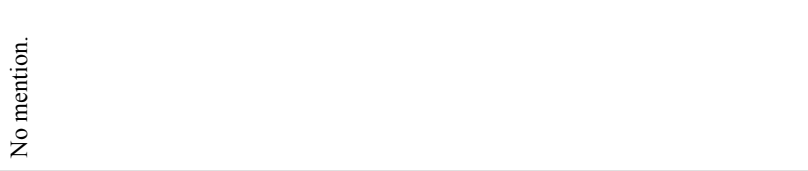 \\
\hline 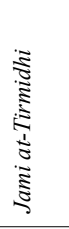 & 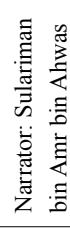 & 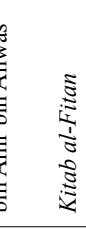 & & 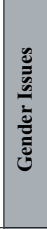 & 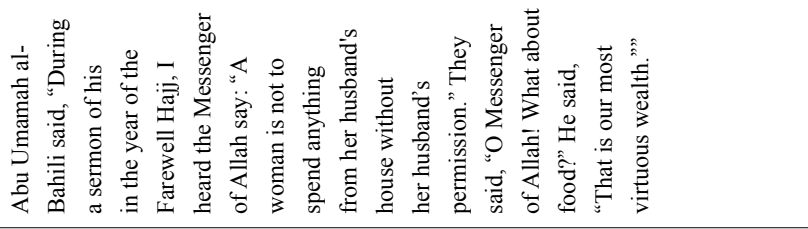 \\
\hline 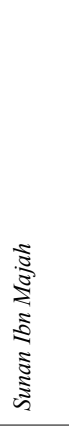 & 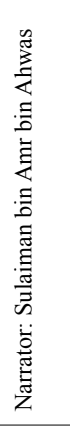 & 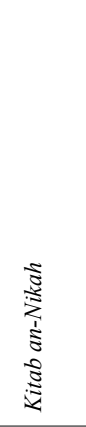 & & 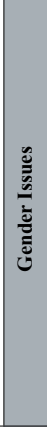 & 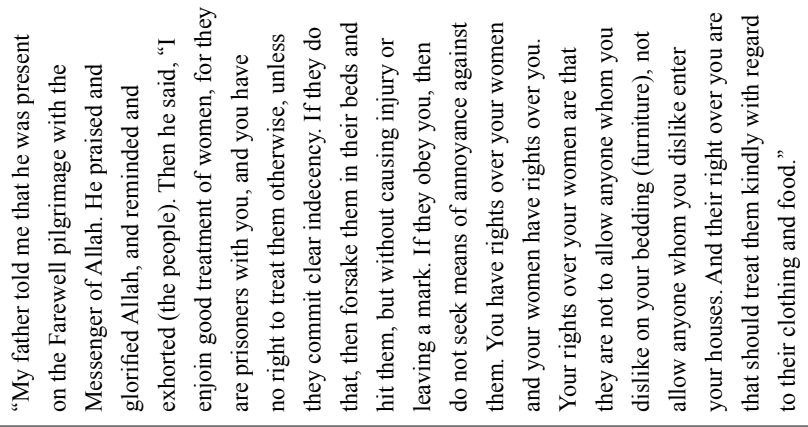 \\
\hline 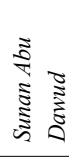 & & 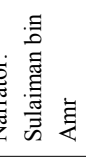 & 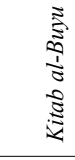 & 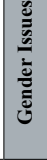 & 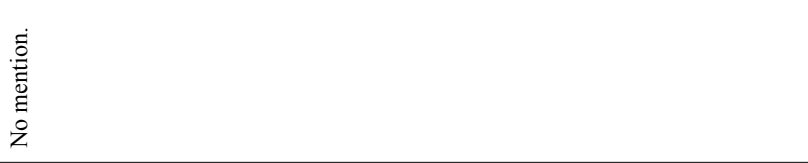 \\
\hline 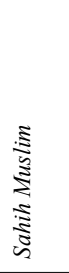 & 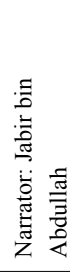 & 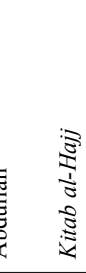 & & 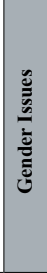 & 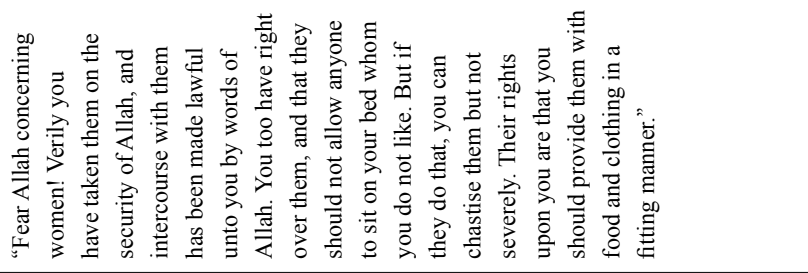 \\
\hline 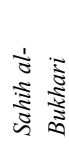 & 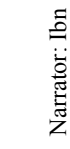 & 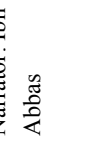 & 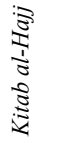 & 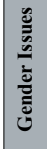 & 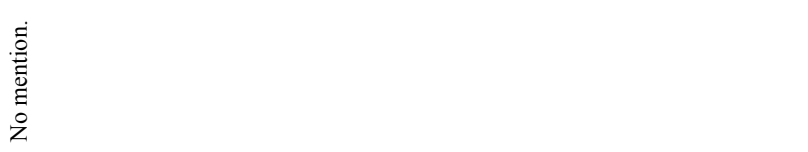 \\
\hline & & & & in & \\
\hline
\end{tabular}




\begin{tabular}{|c|c|c|c|c|c|}
\hline 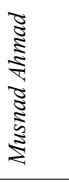 & & & & 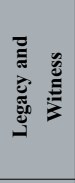 & 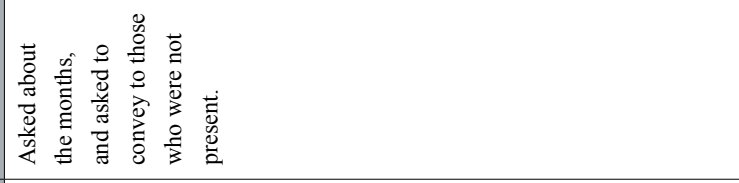 \\
\hline 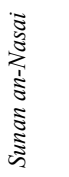 & 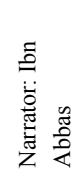 & & 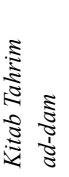 & 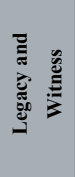 & 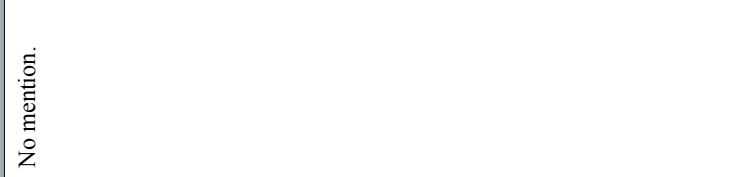 \\
\hline 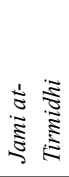 & 崖 & 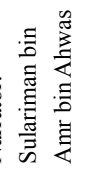 & 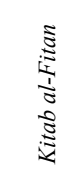 & 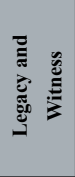 & 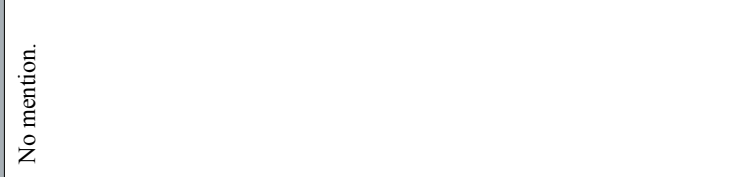 \\
\hline 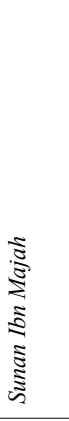 & 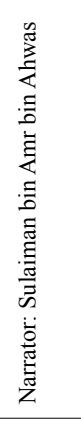 & 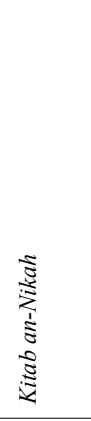 & & 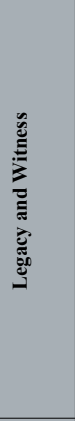 & 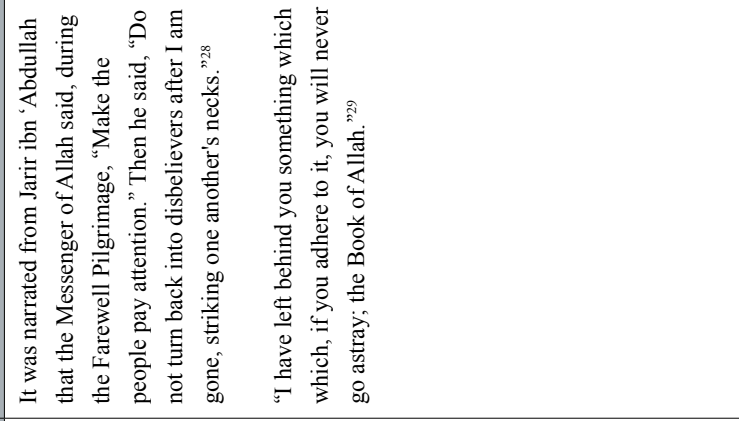 \\
\hline 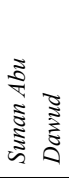 & 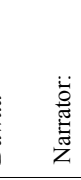 & 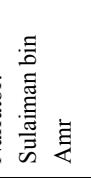 & 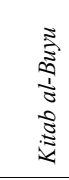 & 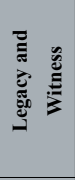 & 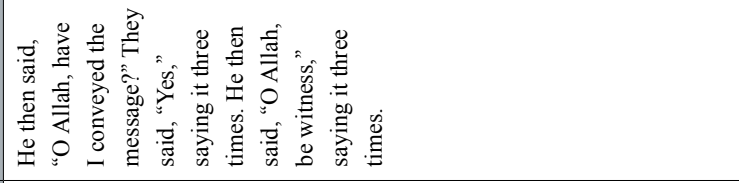 \\
\hline & 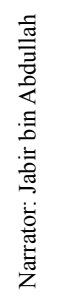 & 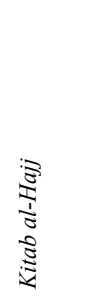 & & 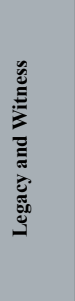 & 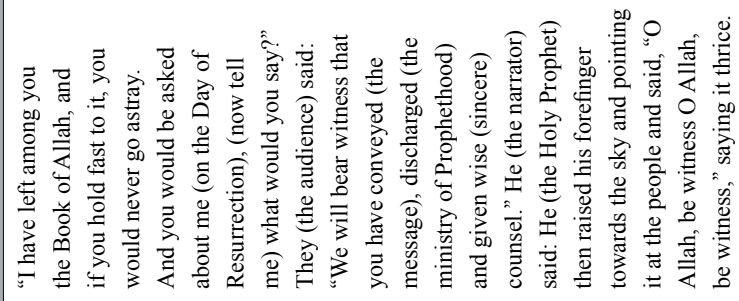 \\
\hline 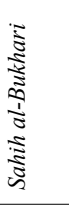 & 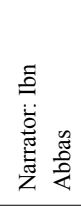 & 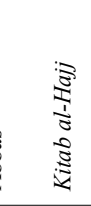 & & 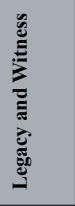 & 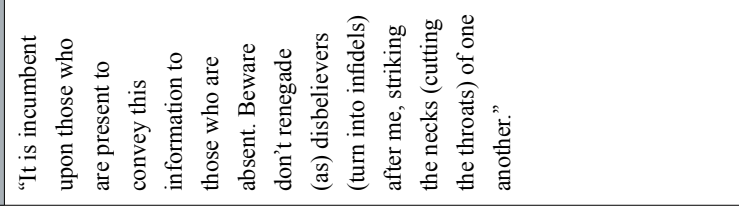 \\
\hline
\end{tabular}




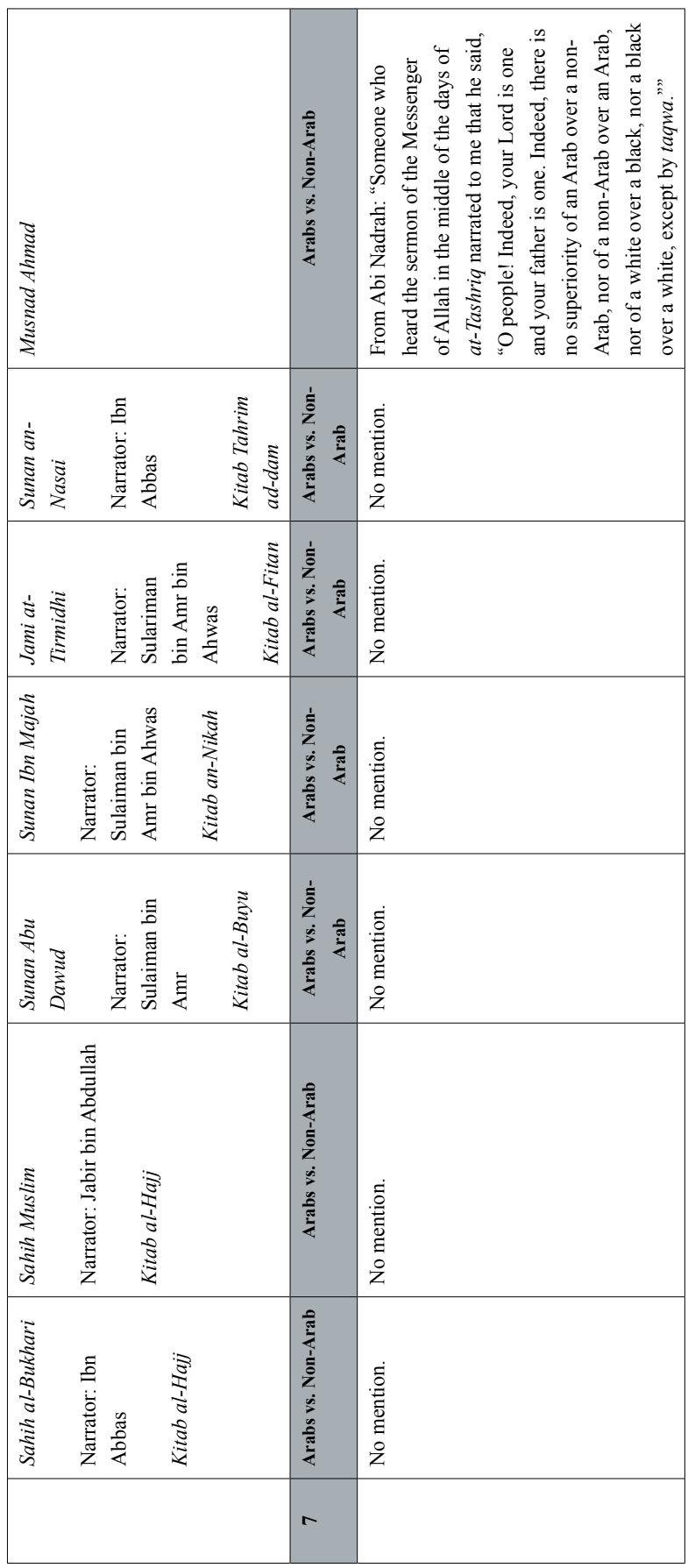




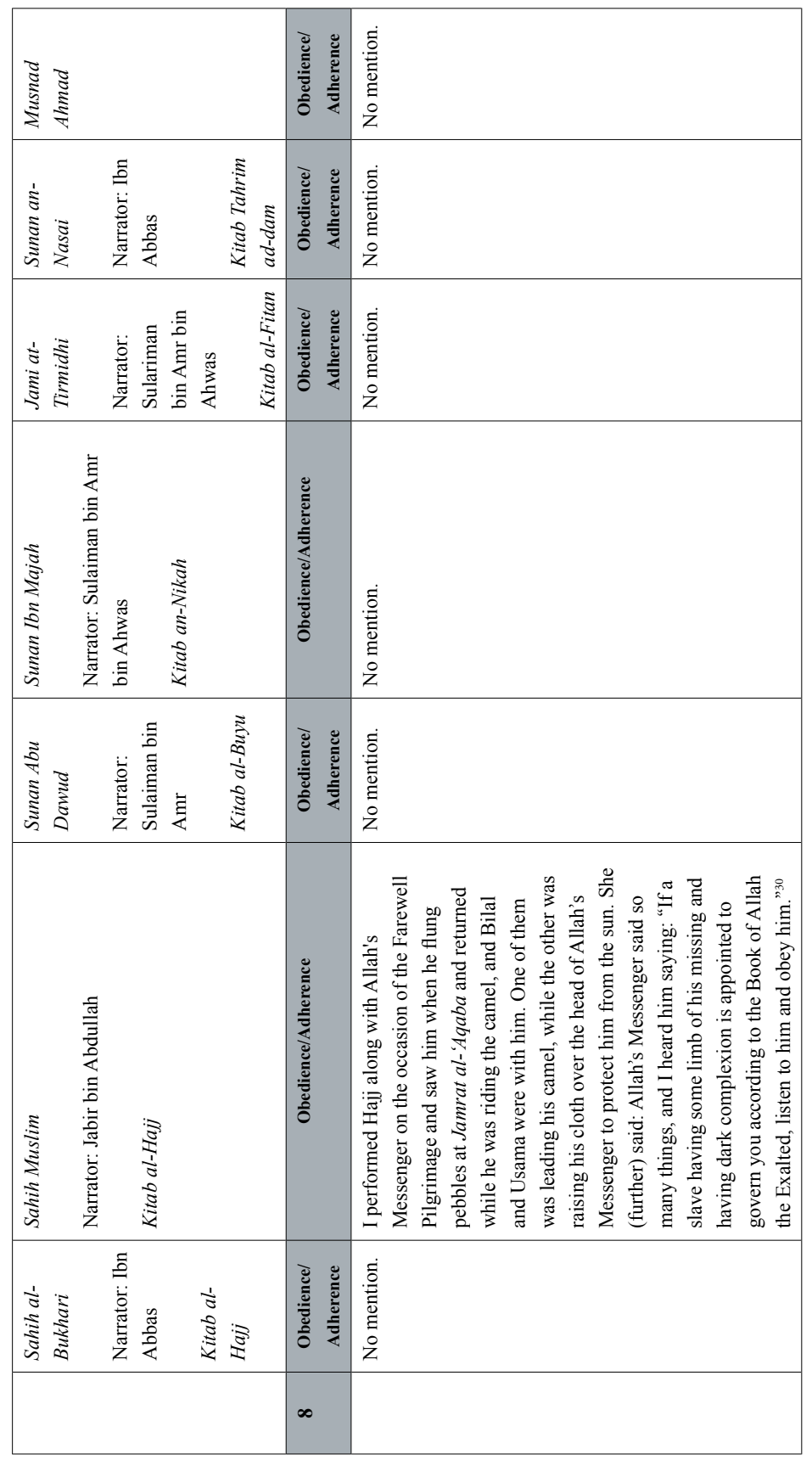




\begin{tabular}{|c|c|c|}
\hline 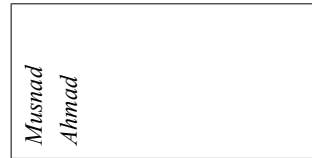 & 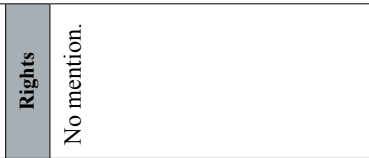 & 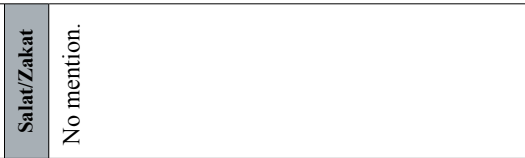 \\
\hline 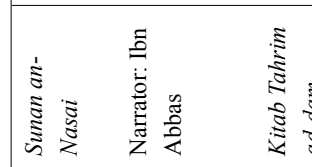 & 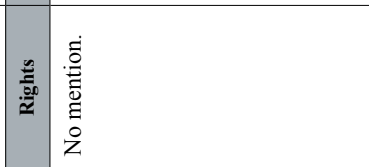 & 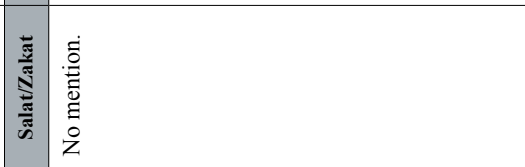 \\
\hline 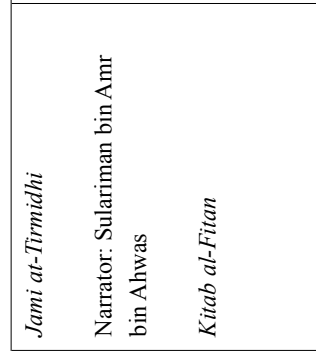 & 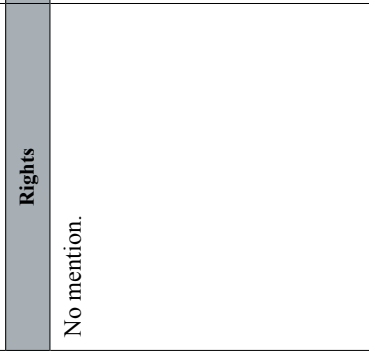 & 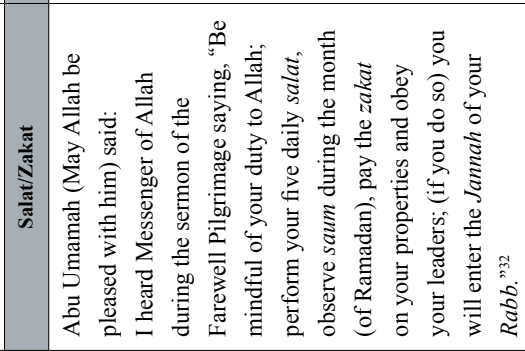 \\
\hline 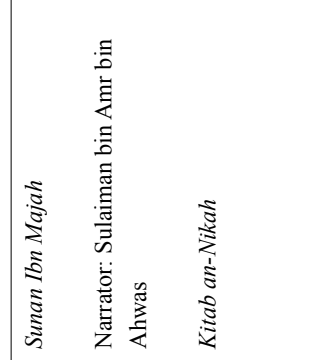 & 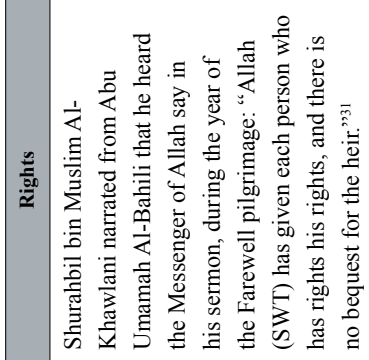 & 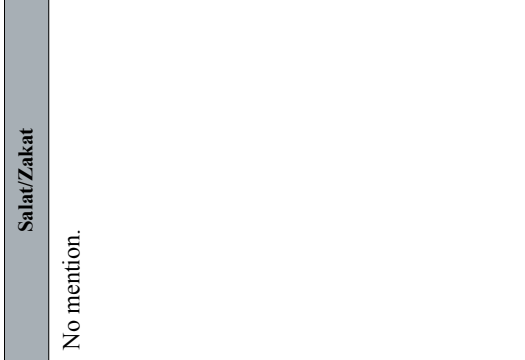 \\
\hline 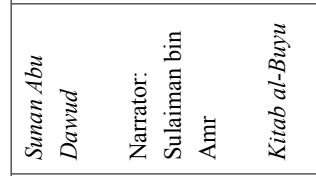 & 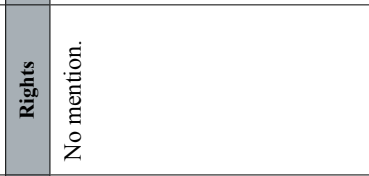 & 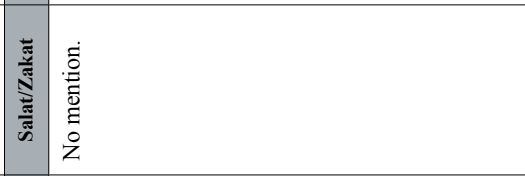 \\
\hline 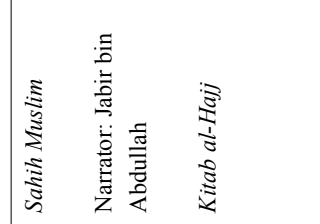 & 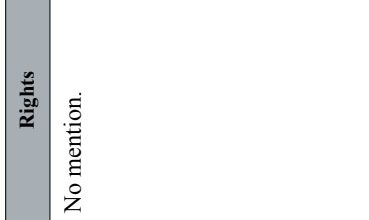 & 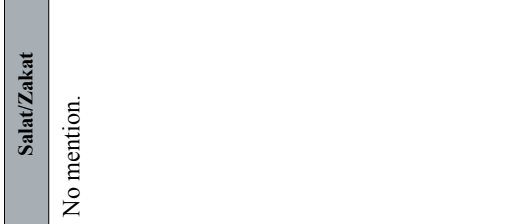 \\
\hline 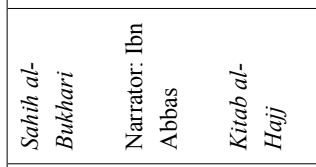 & 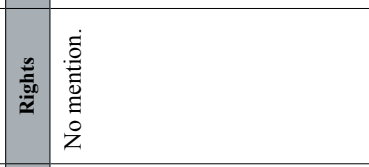 & 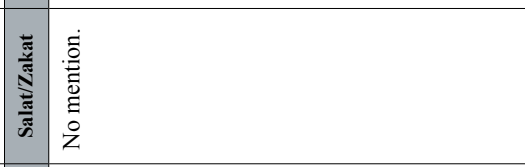 \\
\hline &. & $\cong$ \\
\hline
\end{tabular}




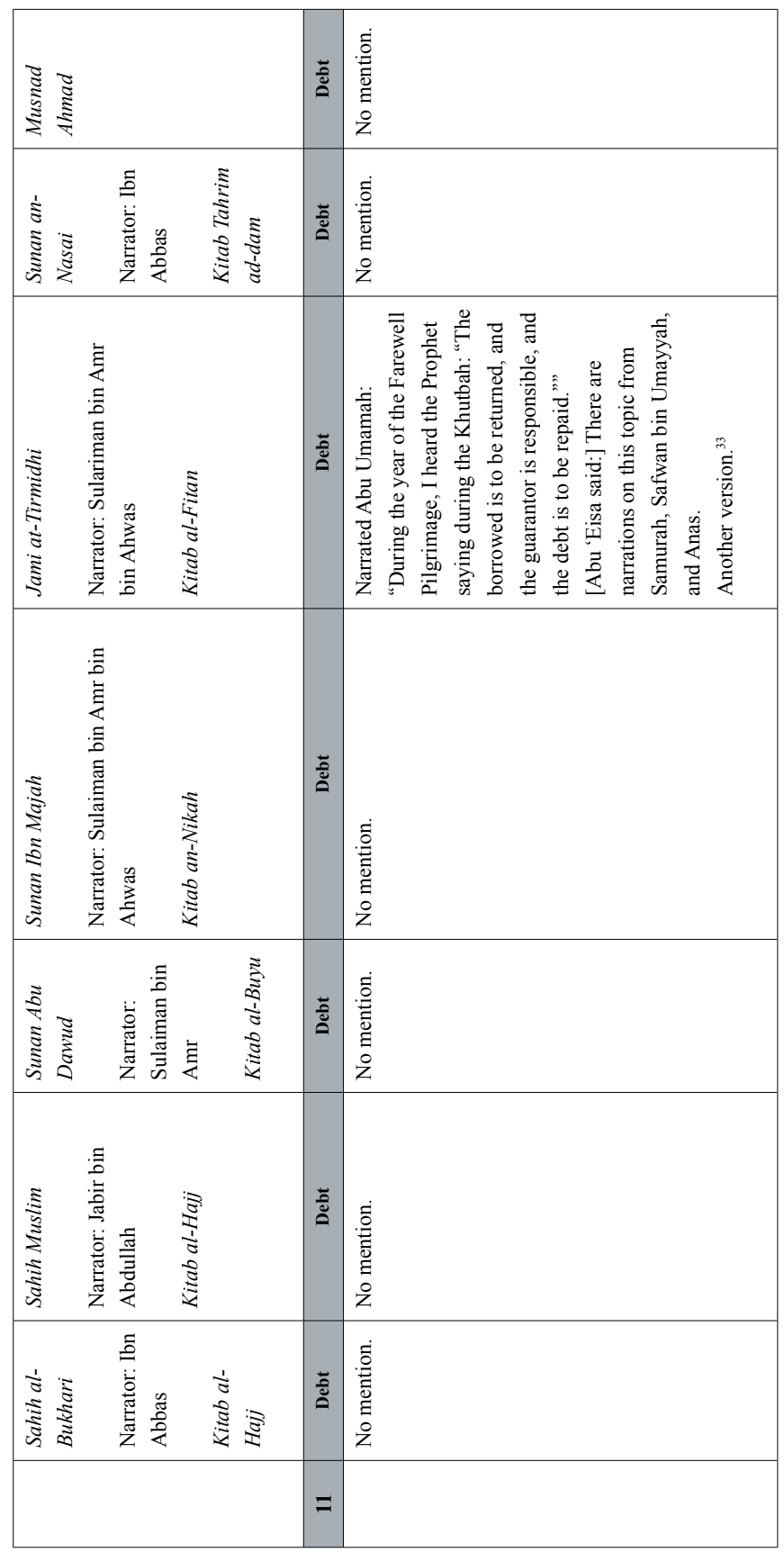




\section{Notes}

* Mohammad Omar Farooq is Associate Professor at the Department of Economics and Finance, University of Bahrain.

1. It is customary among Muslims to give the salutation 'Peace be Upon Him' whenever naming the Prophet Muhammad. This is abbreviated here as (pbuh).

2. Hakan Kosova (Ed.), A Tribute to the Prophet Muhammad (Somerset, NJ: Tughra Books, 2007), https://books.google.com.bh/books/about/The_Farewell_ Sermon_of_Prophet_Muhammad.html?id $=$ CMn_PAAACAAJ\&redir_esc $=\bar{y}$ (Accessē on: January 20, 2018).

3. Coeli Fitzpatrick and Adam Hani Walker (Eds), Muhammad in History, Thought, and Culture: An Encyclopedia of the Prophet of God, 2 Volumes (Santa Barbara, CA: ABC-CLIO, 2014), 269.

4. Ibid., 269.

5. Recep Senturk, 'Human Rights in Islamic Jurisprudence: Why should All Human Beings Be Inviolable?' in The Future of Religious Freedom: Global Challenges, ed. Allen Hertzke (Oxford, UK: Oxford University Press, 2013), 290-314, 293.

6. Suzanne McIntire, Speeches in World History (New York: Infobase Publishing, 2009), 79-81.

7. Benjamin Walker, Foundations of Islam: The Making of a World Faith (Peter Owen, 1998), 170.

8. Initially with four, the scholars identified six books (Kutub al-Sitta) or the Authentic Six (Sihah Sitta). J. Brown, The Canonization of al-Bukhari and Muslim: The Formation and Function of the Sunni Hadith Canon (Leiden: Brill, 2007), 8-9.

9. Abdulhamid AbuSulayman, 'Chastising Women: A Means to Resolve Marital Problems?' ILMU Ushulddin 1, no. 1 (2013), http://journal.uinjkt.ac.id/index. php/ilmu-ushuluddin/article/view/1020 (Accessed on: January 18, 2018).

10. Nafiseh Gharournia, 'Towards a New Interpretation of Quran, 4:34,' Hawwa 15, no. 3, 279-292; Nada Ibrahim and Mohamad Abdalla, 'A Critical Examination of Qur'an 4:34 and Its Relevance to Intimate Partner Violence in Muslim Families,' Journal of Muslim Mental Health 5, no. 3 (2010), 327-349, https:// research-repository.griffith.edu.au/bitstream/handle/10072/38916/69246_1. pdf\%3Bsequence $=1$ (Accessed on: January 25, 2018); Shaheen Sardar Äli, 'Equal before Allah, Unequal before Man? Negotiating gender hierarchies in Islam and International Law,' PhD thesis, University of Hull (1998), https://core. ac.uk/download/pdf/2731703.pdf (Accessed on: February 18, 2018).

11. Abdullah Saeed, Interpreting the Qur'an: Towards a Contemporary Approach (London, UK: Routledge), 2006. See Chapter 11, 'Ethico-legal texts and a hierarchy of values.'

12. \#4155, https://sunnah.com/urn/636690.

13. Muwatta Imam Malik, Kitab al-Qadr, \#1628, https://sunnah.com/urn/416890.

14. Kitab al-Ilm, Bab Khutbatihi fi Hajj al-Wida, \#324. Complete Islamic Reference (Digital Database).

15. Sahih Muslim, Kitab al-Fadail as-Sahaba, \#2903, https://sunnah.com/ muslim/44/58. In this hadith, thaqalain is mentioned, but only the Qur'an is 
identified. In the other hadith in Sahih Muslim, \#5920, both the Qur'an and Ahl alBayt are mentioned. https://sunnah.com/muslim/44/55. This hadith has become the mainstay of Shi'ism as it is deemed to support the view that the Prophet taught the Muslims to adhere to the example of the Ahl al-Bayt along with the Qur'an. However, this view also limits the Ahl al-Bayt to only Ali, Fatima, Hasan and Hussain (May God be pleased with them all). However, exclusion of wives from anyone's household is not sensible and, more importantly, is inconsistent with the Qur'anic use of the term, see the 33:33; 11:72-3.

16. https://en.wikipedia.org/wiki/Farewell_Sermon.

17. https://en.wikipedia.org/wiki/Farewell_Sermon.

18. Sahih al-Bukhari, Kitab al-I'itisam bi al-Kitab wa Sunnah, https://sunnah. com/bukhari/96/93; Sahih Muslim, Kitab al-Wasiya, https://sunnah.com/ muslim/25/31;

19. Mohammad Omar Farooq, In Search of a Hadith: A Journey in Scholarly Due Diligence,' https://ssrn.com/abstract=3062947 (2017) (Accessed on: February 17, 2018).

20. Some rather long hadiths in various collections include: Sahih al-Bukhari, Book of Revelations, \#7, https://sunnah.com/bukhari/1/7; Book of holding fast to the Qur'an and Sunnah, \#37, https://sunnah.com/bukhari/96/36; Book of Tawhid, \#39 https://sunnah.com/bukhari/97/39; Book of Mi'raj, \#113, https://sunnah. com/bukhari/63/113.

21. http://www.sunnah.com/bukhari/25/217.

22. http://sunnah.com/muslim/15/159.

23. http://www.sunnah.com/abudawud/23/9.

24. https://sunnah.com/urn/1261680.

25. https://sunnah.com/tirmidhi/33/2.

26. http://sunnah.com/nasai/37/166.

27. http://library.islamweb.net/newlibrary/display_book.php?idfrom=22393 \&idto= $22393 \& b k$ no $=6 \& I D=1079$.

28. http://sunnah.com/ibnmajah/36/17.

29. https://sunnah.com/urn/1281040.

30. http://sunnah.com/muslim/15/342.

31. http://sunnah.com/urn/1270300.

32. http://sunnah.com/riyadussaliheen/1/73.

33. http://sunnah.com/tirmidhi/6/73. 